\title{
Sonhos e Cartas de Marear
}

António Faria-Vaz*

Eles não sabem, nem sonham,

Que o sonho comanda a vida.

Que sempre que um homem sonha

O mundo pula e avança

António Gedeão

E defendo-me da morte povoando

De novos sonhos a vida

Alexandre O'Neill

S onhar, enquanto desejo de um ideal de futuro, é o convite que vos endereçamos neste número da revista. Para tal, dispomos de um conjunto de textos que de uma forma invulgar procuram, cada um à sua maneira, solicitar a nossa disponibilidade para reflectirmos sobre a governação clínica, a reforma dos Cuidados Primários de Saúde e a humanização dos cuidados de saúde.

Sonha-se e respira-se ao lermos o texto da nossa colega Maria José Ribas. De facto, a sua abordagem permite-nos vislumbrar os atributos humanos, clínicos e científicos de um médico de família ideal. Ideal, não no sentido de uma utopia que, por definição, será sempre perseguida e nunca conseguida, mas de uma condição que nos é exigida e que devemos procurar cumprir: a de um médico que respeita a relação e o compromisso com o seu doente. Respeito na interacção com o outro, na disponibilidade para ouvir e sentir, na generosidade, na simpatia e empatia, na pontualidade. Respeito pelo outro, na medida em que procura cumprir o dever ético de se manter actualizado, garantindo que presta, em cada momento, os melhores cuidados possíveis aos seus doentes. Respeito pelos outros, respeito por todos

*Director da Revista Portuguesa de Clínica Geral os que partilham connosco a tarefa de prestação de cuidados de saúde, respeito que se centra na convicção assumida de que o cabal cumprimento da "governação clínica e de saúde» implica o concurso de outras competências e de outros saberes que concorrem para o mesmo fim. Respeito pelo outro na medida em que organiza o seu trabalho de tal forma que consegue que $o$ doente seja o centro da sua atenção, partilha saberes e as competências, optimiza os recursos e contribui para a efectividade dos cuidados de saúde.

O texto de Maria José Ribas é também uma carta de marear. Sigamo-la e o sonho aportará em seguro ancoradouro. ${ }^{1}$

Sigamos também o rumo reflexivo do Professor Walter Oswald na transição para Medicina da próxima década. Distanciamento progressivo entre médico e doente, rupturas da relação clínica e da confiança justificam a preocupação de quem, não concebendo a Medicina sem Humanismo, chama a atenção para a importância determinante de factores como a sustentabilidade do sistema de saúde, a reforma da estrutura do serviço nacional de saúde, as prioridades emergentes em saúde (a medicina geral e familiar; os cuidados continuados e os cuidados paliativos) e as políticas de utilização de tecnologias em saúde.

Para o Prof. Walter Osswald, «a humanização será o grande desafio e a regra a adoptar para que as técnicas sirvam os melhores interesse dos doentes e não os secundarizem e muito menos coisifiquem $»^{2}$. A emergência de novas tecnologias médicas e a despersonalização dos cuidados médicos são desafios que podem pôr em causa valores fundamentais como a liberdade e a dignidade dos cidadãos, sujeitando a enorme pressão a confiança no saber e a idoneidade moral em que assenta a relação médico-doente. Nesta circunstância, caberá aos médicos a persistência em práticas humanistas que garantam a salvaguarda do compromisso de se manterem ao serviço dos doentes.

Outro dos nossos temas desta edição é a desigualdade no acesso aos cuidados de saúde no Serviço Nacional de Saúde. A «endemia silenciosa» dos doentes 
sem médico de família constitui justificação para se reflectir sobre a equidade horizontal em saúde e sobre as repercussões da reforma dos cuidados primários (CP) e da implementação das Unidades de Saúde Familiar. Agravadas, em alguns casos, pela reorganização dos CP, as desigualdades no acesso aos cuidados de Saúde tendem a atingir em particular as populações vulneráveis, onde se incluem os idosos e os cidadãos com fragilidades acrescidas, conjunturais ou não. Assumindo com algum realismo que a resolução da carência de médicos de família não será resolvida, a curto nem a médio prazo, são-nos sugeridos novos paradigmas para a prestação de cuidados de saúde às populações. ${ }^{3}$ Sem que tal signifique a sua mercantilização nem o agravamento da acessibilidade, como quase sempre acontece quando se substitui a prestação dos serviços públicos por serviços privados. Sabemos que a captura dos serviços de saúde por prestadores privados implicou quase sempre e a breve trecho um aumento dos custos, uma redução da qualidade, um acréscimo da despesa pelos cidadãos e um incremento da desigualdade.

Certamente que não são consensuais as soluções propostas, em particular a possibilidade de se substituir o médico pelo enfermeiro. Por seu turno, a escassez de médicos é uma justificação que apenas fragiliza qualquer proposta de maior colaboração entre os diferentes grupos de profissionais. No entanto, poderá ser oportuna uma análise de possíveis mudanças dos paradigmas corporativos actuais, desde que centradas no exame e respeito das competências, das aptidões e atitudes dos profissionais que concorrem para a prestação de cuidados de saúde, sobretudo se a carta de marear nos fizer aproar à continuidade de cuidados e ao incremento da eficiência do serviço prestado pelos cuidados de saúde primários.
Dito isto, poderíamos afirmar que muito falta ao cumprimento cabal da reforma, que muito há fazer, que muito há a construir. Falta, sobretudo, aprofundar a governação clínica e a governação em saúde.

Trata-se, como afirma Correia de Campos, de as organizações de saúde aceitarem o compromisso de cumprirem padrões elevados de qualidade como uma responsabilidade de cariz ético-social. ${ }^{4} \mathrm{E}$, por outro, a governação clínica e a sua contraparte, a governação em saúde, exigem o esforço de toda a equipa de saúde envolvida na prestação de cuidados de saúde. Implicam a incessante busca das vias mais apropriadas ao cumprimento dos objectivos de saúde e o empenho na reengenharia de processos, em novos delineamentos organizacionais, no estabelecimento de novas prioridades $\mathrm{e}$ de novos objectivos individuais, além de requererem, em muitos locais, completas reviravoltas nos relacionamentos inter-profissionais. Exigirá, por certo, muito fôlego, mas estamos a tratar de um objectivo estratégico máximo: a satisfação das necessidades de saúde dos cidadãos, razão primeira e última dos serviços de saúde.

Cumprir a reforma dos cuidados primários de saúde é, pois, tarefa inacabada. Reflectir e propor soluções é o contributo que nos dispomos a levar a cabo.

Boas leituras.

\section{REFERÊNCIAS BIBLIOGRAFICAS}

1. Ribas MJ. Projectar uma década - que coordenadas para o futuro da medicina geral e familiar?. Rev Port Clin Geral 2010; 26: 177-82

2. Osswald W. Uma Medicina para a nova década? Rev Port Clin Geral 2010; 26: 184-7

3. Cortez I. Desigualdade no acesso aos Cuidados Primários de Saúde - a outra face das USF. Ver Port Clin Geral 2010; 26: 189-94

4. Campos AC. Reformas da Saúde : o fio condutor. $1^{\text {a }}$ edição. Coimbra : Edições Almedina; 2008. 